\title{
Standardized Correlations and Path-Coefficient Analysis for Seed Yield in Four Populations of Egyptian Multi-Cut Barseem Clover
}

\author{
"Trifolium Alexandrinum,L."
}

\author{
Asmaa Mohamed Samir Rady \\ Crop Science Dept., Faculty of Agriculture (El-Shatby), Alexandria University \\ (asmaa.mohamed@alexu.edu.eg).
}

\begin{abstract}
The objective of the present study was to determine through path-analysis the significant role of seed yield components in the yield of barseem seed, their interrelationships and relative importance, considering four variable population. In all studied multi-cut barseem populations, number of heads.plant ${ }^{-1}$ was the most positively correlated trait with total seed yield. While, seed weight.head ${ }^{-1}$ was of moderate correlation with total seed weight in three out of the four populations (Alexandria I, Meskawi and Helaly). Also number of seeds.head ${ }^{-1}$ was of moderate positive correlation with total seed weight in only two populations (Meskawi and Helaly). The strongest positive correlation was expressed between number of seeds.head ${ }^{-1}$ and seed weight.head- ${ }^{1}$ in all studied barseem populations. This latter results might indicate that seed weight.head ${ }^{-1}$ might influence the total seed yield through number of seed.head ${ }^{-1}$.
\end{abstract}

Keywords: Path-analysis, Correlation, Seed yield, Barseem clover.

\section{INTRODUCTION}

Barseem clover "Trifolium alexandrinum,L."is the basic forage crop in Egypt. Production cycle of barseem vary depending on plant type. Fahl type is a single cut of short cycle. Meskawi type has a long production cycle extends for more than six months. Both types are included in rotations depending upon the principle cash crop's time of sowing.

Breeding for improved seed yield potentiality in barseem clover requires a preliminary studies regarding seed yield components that determine total yield of seeds. Such information is critical, since, indirect selection through related traits is more efficient in terms of selection gain. Moreover, Vencovsky and Belly (1992), stated that, informations regarding characters related to a major character of interest for breeders, prevent any loss of control over the behaviour and harmonic balance among the vectors related to productivity, which represent a core component for good characterization of a new cultivar. In the meantime, Annicchiarico (1993), postulated that, in most forage breeding programes high seed yield is completing the goal of high forage production. Such goal is not easily attained, unless clear illustration of how interrelated traits are expressed. Such detailing allow for more precise breeding results.

Correlation analysis evaluate the relationship between variables. Relations between characters of barseem clover were detected by several workers, (Radwan et al, 1983; Bakheit and Mahdy, 1988; Ahmed, 1992; Ahmed, 2000 Abdel Gawad, 2003 and Ahmed, 2006). However, this type of analysis does not drive conclusions about cause and effect relationships.

Path- coefficient analysis provides estimates of direct and indirect effects on one trait via other variables. Many workers gave results with forage crops evaluating seed yield components (Bakheit, 1986; Iannucci and Martiniello, 1998, Lord and Kelly, 1999 and Ahmed, 2006). So far,the influence of seed yield components on total seed yield of berseem clover had not extensively studied.

The objective of the present study was to determine through path- analysis the significant role of seed yield componentes in the yield of barseem seed, their interrelationships and relative importance, considering four variable population. It was hoped that such results lead breeders for more efficient seed production breeding programs.

\section{MATERIALS AND METHODS}

Four distinguished multi-cut populations of barseem clover (Trifolium alexandrinum L.) were chosen for this study. Alexandria I is an improved population via selection for successive cycles in Alexandria university (Ahmed,2000). Meskawi, Saidy and Helaly are commercial population realized by forage research section, Agriculture Research center, Giza, Egypt. Each population was seeded in the Agricultural Experimental station of Alexandria university during 2015-2016 season. Seeding rate was $31.4 \mathrm{~kg} \cdot \mathrm{ha}^{-1}$, hand drilled in rows $4.0 \mathrm{~m}$ long and $0.2 \mathrm{~m}$ apart (2.5g.plot ${ }^{-1}$ ). At flowering 300 plants from each population were randomly selected. Seeds harvested from each separate plant were saved as a half-sib family. One 
hundered half-sib families with enough seeds from each population were saved. In 2016-2017 winter season, half-sib families of each population were evaluated in a separate experiment. Sowing dates were $12^{\text {th }}, 15^{\text {th }}$ and $17^{\text {th }}$ of october, 2017 for Alexandria I, Meskawi, Saidy and Helaly, respectively. Each experiment was carried-out as a randomized complete block design with three replicates. Each half-sib family was sown in a single row $1.5 \mathrm{~m}$ long and $20 \mathrm{~cm}$ apart. Seeding rate was 31.4 kg.ha ${ }^{-1}$ (1.03g.plot $\left.{ }^{-1}\right)$. Family rows was alternated with single row of a composte seed representing the four base populations. Five cuttings were taken after 60,100,135,165 and 195 days from sowing in each experiment before allowing plants to flower. Seed yield (total seed weight) was determined for each half-sib family from the middle $0.75 \mathrm{~m}$ of plot row. Seed yield components i.e.; number of heads / plant, seed weight/ head, number of seeds / head and 1000 seed weight were determined as an average of ten random plants in each plot.

Data collected were standardized $[\mathrm{x}=(\mathrm{x}-\mathrm{m} / \mathrm{sd})]$ before a regression analysis was carried out using excell. Regression on a standardized variablels gives partial regression coefficients unlike regression on nonstandardized variables that gives concrete regression coefficients. Partial regression coefficients are in fact another name for direct path coefficients (Akintunde, 2012). The path correlation analysis was carried-out according to the procedure applied by Dewey and Lu (1959). The path analysis partitions the correlation coefficient into direct and indirect effects through alternate path ways $\left(r_{x p}\right)$. Total seed yield was selected as the resultant variable and other traits (fig1) as causal factors.

\section{RESULTS AND DISCUSSION}

Corelation between total seed yield and four seed yield compunents i.e; number of heads.plant ${ }^{-1}$, number of seeds.head ${ }^{-1}$, seed weight. head ${ }^{-1}$ and 1000 seed weight for multi-cut barseem populations are presented in Table(1). It was obvious that, all seed yield component characters had a positive correlations with total seed weight, indicating that, they influence in one way or another the expression of that character. This result was true with all studied four barseem populations.

As for, Alexandria I population, the strong positive corelation with total seed weight was expressed by number of heads.plant ${ }^{-1}$ (0.794). While, moderate positive correlation was presented by seed weight.head ${ }^{-1}(0.359)$. Meanwhile, both of number of seeds. head ${ }^{-1}$ and 1000 seed weight showed weak correlations $(r=0.197$ and 0.005 , respectively). In the meantime, mean of seed yield components had a strong corelation with number of heads. Plant ${ }^{-1}(r=0.065,0.005$ and 0.082 for correlations with seed weight.head ${ }^{-1}$, number of seeds. head ${ }^{-1}$ and 1000 seed weight, respectively). Also, 1000 seed weight had weak correlations with seed weight.head ${ }^{-1}$ and number of seeds. head ${ }^{-1}$ ( $r=0.014$ and 0.041 , respectively). Number of seeds. Head ${ }^{-1}$ had a moderate correlation with seed weight. head ${ }^{-1}(r=0.425)$

Regarding Meskawi population, the most obvious strong positive correlation with total seed yield was presented by number of heads.plant ${ }^{-1}(\mathrm{r}=$ 0.864) along with moderate correlations expressed by number of seeds.head ${ }^{-1}$ and seed weight.head ${ }^{-1}$ $(\mathrm{r}=0.321$ and 0.322 , respectively). Meanwhile, number of seeds. head ${ }^{-1}$ was strongly positively correleted with seed weight. head ${ }^{-1}(r=0.992)$. Other correlations between pairs of seed yield components were relatively weak.
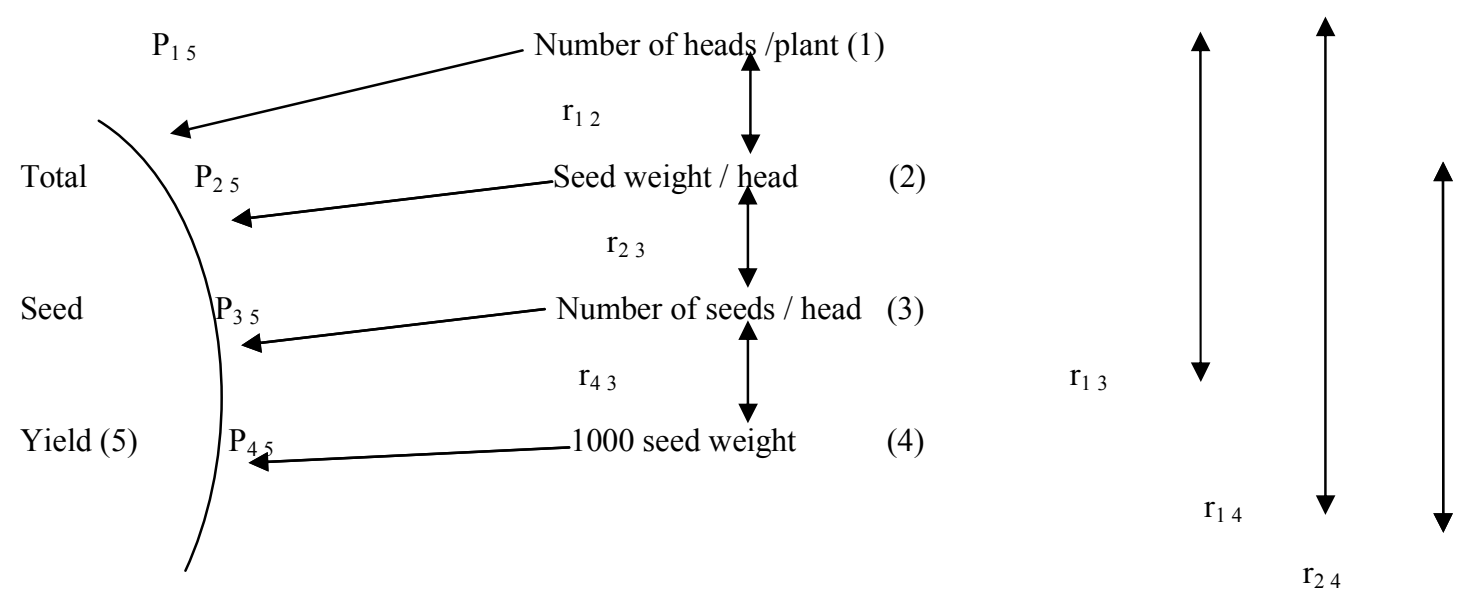

Fig.1: Path diagram showing causal relationships of four predictor variables with the response variable total seed yield. One directional arrow $(\rightarrow)$ reprresent direct path $(P)$ and two directional arrows $\longleftrightarrow$ represent correlation $(r)$. 
Table 1: Phenotypic $\left(r_{p}\right)$ correlation coefficient among characters of 100 half-sib families of AlexandriaI, Meskawi, Saidy and Helaly multi -cut barseem clover.

\begin{tabular}{lccccc}
\hline & \multicolumn{5}{c}{ Alexandria I } \\
& $\begin{array}{c}\text { Number of } \\
\text { heads/plant }\end{array}$ & $\begin{array}{c}\text { Number of } \\
\text { seeds/ head }\end{array}$ & $\begin{array}{c}\text { Seed weight } \\
\text { /head }\end{array}$ & $\begin{array}{c}\mathbf{1 0 0 0} \text { seed } \\
\text { weight }\end{array}$ & $\begin{array}{c}\text { Total seed } \\
\text { weight }\end{array}$ \\
\hline Number of heads/plant & 0.005 & 0.065 & 0.082 & 0.794 \\
\hline Number of seeds/ head & & 0.425 & 0.041 & 0.197 \\
\hline Seed weight /head & & & 0.014 & 0.359 \\
\hline 1000 seed weight & & & & 0.005 \\
\hline Total seed weight & & & & \\
\hline
\end{tabular}

\begin{tabular}{lccccc}
\hline & $\begin{array}{c}\text { Number of } \\
\text { heads/plant }\end{array}$ & $\begin{array}{c}\text { Number of } \\
\text { seeds/ head }\end{array}$ & $\begin{array}{c}\text { Seed weight } \\
\text { /head }\end{array}$ & $\begin{array}{c}\mathbf{1 0 0 0} \text { seed } \\
\text { weight }\end{array}$ & $\begin{array}{c}\text { Total seed } \\
\text { weight }\end{array}$ \\
\hline Number of heads/plant & 0.079 & 0.077 & 0.062 & 0.864 \\
\hline Number of seeds/ head & & 0.992 & 0.081 & 0.321 \\
\hline Seed weight /head & & & 0.071 & 0.322 \\
\hline 1000 seed weight & & & & 0.069 \\
\hline Total seed weight & & & & \\
\hline
\end{tabular}

\begin{tabular}{lccccc}
\hline & $\begin{array}{c}\text { Saidy } \\
\text { humber of } \\
\text { heads/plant }\end{array}$ & $\begin{array}{c}\text { Number of } \\
\text { seeds/ head }\end{array}$ & $\begin{array}{c}\text { Seed weight } \\
\text { /head }\end{array}$ & $\begin{array}{c}\mathbf{1 0 0 0} \text { seed } \\
\text { weight }\end{array}$ & $\begin{array}{c}\text { Total seed } \\
\text { weight }\end{array}$ \\
\hline Number of heads/plant & 0.017 & 0.02 & 0.03 & 0.766 \\
\hline Number of seeds/ head & & 0.995 & 0.003 & 0.152 \\
\hline Seed weight /head & & & 0.002 & 0.152 \\
\hline 1000 seed weight & & & & 0.042 \\
\hline Total seed weight & & & & \\
\hline
\end{tabular}

\begin{tabular}{lccccc}
\hline & \multicolumn{5}{c}{ Helaly } \\
\hline & $\begin{array}{c}\text { Number of } \\
\text { heads/plant }\end{array}$ & $\begin{array}{c}\text { Number of } \\
\text { seeds/ head }\end{array}$ & $\begin{array}{c}\text { Seed weight } \\
\text { /head }\end{array}$ & $\begin{array}{c}\mathbf{1 0 0 0} \text { seed } \\
\text { weight }\end{array}$ & $\begin{array}{c}\text { Total seed } \\
\text { weight }\end{array}$ \\
\hline Number of heads/plant & & 0.047 & 0.039 & 0.082 & 0.828 \\
\hline Number of seeds/head & & 0.973 & 0.014 & 0.363 \\
\hline Seed weight /head & & & 0.016 & 0.366 \\
\hline 1000 seed weight & & & & 0.122 \\
\hline Total seed weight & & & & &
\end{tabular}

Total seed weight

Concerning Saidy barseem population, a positive strong correlation with total seed yield was presented by number of heads. plant ${ }^{-1}(r=0.766)$. In the meantime, another strong correlation a given by number of seeds. head ${ }^{-1}$ and seed weight. head ${ }^{-1}(\mathrm{r}=$ 0.995). Correlations with each of seed weight. head ${ }^{-1}$ and number of seeds. head ${ }^{-1}$ were obviously weak ( $\mathrm{r}=0.152$ for both correlations).

Helaly population showed that, the most positively correlated trait with total seed yield was number of seeds. head ${ }^{-1}(\mathrm{r}=0.828)$ while, medium correlations were shown with each of number of seeds. head ${ }^{-1}$ and seed weight. head ${ }^{-1}(r=0.363$ and 0.366 , respectively). In the meantime, number of seeds. head ${ }^{-1}$ was strongly correlated with seed weight. head ${ }^{-1}(r=0.973)$.

Commonly, in all studied multi-cut barseem populations, number of heads. Plant ${ }^{-1}$ was the most positively correlated trait with total seed yield.
While, seed weight. head ${ }^{-1}$ was of moderate correlation with total seed yield in three out of the four studied populations (Alexandria I, Meskawi and Helaly). Also number of seeds.head ${ }^{-1}$ was of moderate positive correlation with total seed yield in only two populations (Meskawi and Helaly). The strongest positive correlation was expressed between number of seeds. head ${ }^{-1}$ and seed weight head in all studied barseem populations. This latter results might indicate that seed weight. head ${ }^{-1}$ might influence the total seed yield through number of seeds. head ${ }^{-1}$.

Path correlation analysis provides direct and indirect effects via predictor characters. Pathanalysis extends multiple regression analysis, but while regression gives the best or closest prediction of the response variable based on the given causal factors by the method of least squares, path analysis goes further by providing probable interpretation of 
the relationship between and within the contributing causal factors to the observed effects (Akintunde, 2012). The effect of each seed yield component character on total seed yield was illustrated in Table(2). In Alexandria I population, number of heads.plant ${ }^{-1}$ had the highest direct effect on total seed weight $(0.275)$, whereas, showed the highest indirect effect via 1000 seed weight. Weak correlations between 1000 seed weight, total seed yield and seed weight.head ${ }^{-1}$, number of seeds head $^{-1}$ might be responsible for their weak indirect efects on total seed weight. The superiority of indirect effect of 1000 seed weight via number of heads . plant $^{-1}$ irrespective of the very weak correlation of that character with total seed yield, might indicate that number of heads.plant ${ }^{-1}$ is affected by another unstudied characters of relation to total seed weight. In Meskawi population, number of heads.plant ${ }^{-1}$ had the highest direct effect on total seed weight $(0.845)$. Whereas, a moderate direct effect was expressed by seed weight. head ${ }^{-1}$ (0.281). The highest indirect effect on total seed weight shown by number of seeds.head ${ }^{-1}$ via seed weight. head ${ }^{-1}$. That indirect effect was supported by the strong correlation between number of seeds.head $^{-1}$ and seed weight.head ${ }^{-1}$ that approximated unity. Regarding saidy population, the highest direct effect on total seed weight. plant $^{-1}$ was scored by number of heads. plant ${ }^{-1}(0.769)$. The second sound direct effect was presented by seed weight. head ${ }^{-1}(0.199)$. While, the highest indirect effect was presented by number of seeds.head ${ }^{-1}$ via seed weight. head ${ }^{-1}$. As for Helaly population, the highest positive direct effect on total seed weight scored by number of heads.plant ${ }^{-1}(0.812)$. Whereas, a second rank positive direct effect represented by seed weight.head ${ }^{-1}$ (0.327). Also, the highest indirect effect on total seed weight.plant ${ }^{-1}$ represented by number of seeds. head ${ }^{-1}$ via seed weight. head ${ }^{-1}(0.318)$.

The available review regarding seed yield component in barseem clover is relatively rare. Jahufer and Gawler,(2000), reported that, seed yield components in white clover scored the highest correlation between the number of inflorescences and seed production. Annicchiaris,(1993) found that, white clover's inflorescences per area was the most correlated with seed production. Low correlation between seed yield component characters might due to low variability in any of the two characters (Crusius, 1997). Iannucci and Martiniello (1998) studied four species of Trifolium and found that, the least variability among seed yield component traits was the weight of thousand seeds.

Table 2: Path-coefficient analysis of mean seed weight-head ${ }^{-1}$, mean number of seeds.head ${ }^{-1}$, mean $1000^{-1}$ seed weight and head number of heads $/$ plant $^{-1}$ upon total seed weight at phenotypic levels of multicut barseem clover populations.

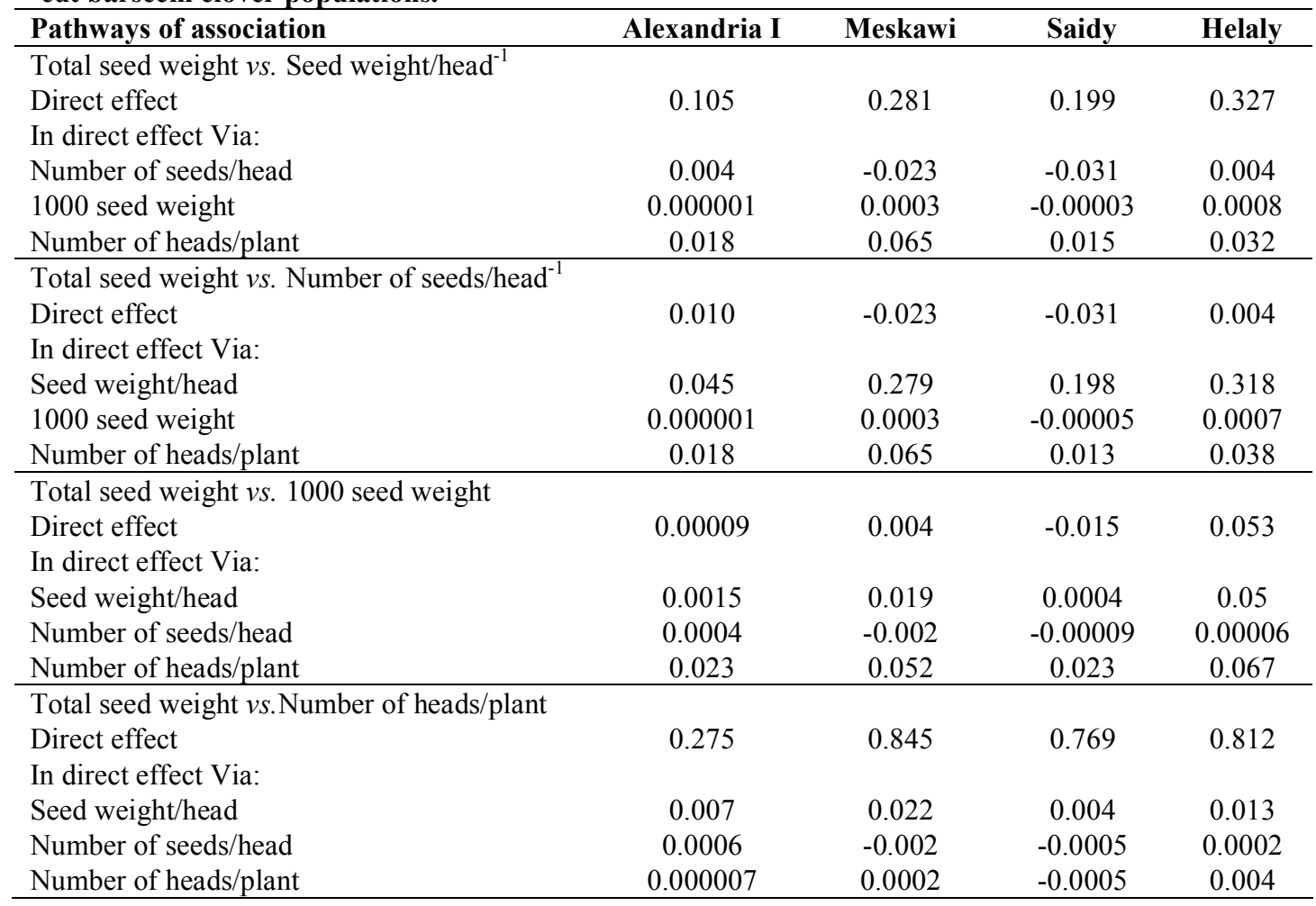


Moreover, Annicchiarico, (1993) reached a high positive correlation $(r=0.89)$ between thousand seed weight and seed production in natural population of white clover (Trifolium repens, L.). Thus, seed yield component depending on this variability in a given population, might be significant in determining seed yield. Research work with path analysis for seed yield in barseem clover is relatively limited. Studies with other species of the genous Trifolium have shown that, the main component affecting seed yield vary greatly according to the species (Iannucci and Martiniello, 1998). Those authors also stated that, in Trifolium species that has short season duration (T.incarnatum, L. and T.resupinatum, L.), character that most influenced seed yield was dry matter yield, while species with long season duration (T.alexandrinum, L.) had more complex interrelationships between production components, where both the weight of seeds, as the number of seeds per inflorescence and the number of inflorescences per stem were important. Another method for evaluating the relationships among seed yield components is through principel component analysis. Crusius(1997) stated that seed production in red clover was significantly estimated by the number of seeds per plant, number of inflorescences per plant and number of stem per plant. Annicchiarico (1993) throught analysis of prinicipel companents, stated that, the weight of thousand seeds and number of flowers per inflorescence were the most influencing characters to seed yield of white clover.

Commomly, in all studied multi-cut barseem population, although the magnitude of correlations between seed yield components were variable, the highest positive direct effect on total seed weight was presented by number of heads.plant ${ }^{-1}$. Whereas, a second rank of positive direct effect was scored by seed weight.head ${ }^{-1}$. Whereas, the strongest indirect effect was that of number of seeds.head ${ }^{-1}$ via seed weight.head ${ }^{-1}$.

\section{REFERENCES}

Abdel Gawad, M.A.S. 2003. Variation on quantity and quality of some barseem cultivars (Trifolium alexandrinum, L.). J. Agric. Sci. Mansoura Univ., 28(2): 719 - 728. Mansoura Univ; Egypt.

Ahmed, M. Abd EL-Sattar, 1992. Improvement of barseem clover (Trifolium alexandrinum, L.) by different methods of selection. Ph-D- Thesis, Fac. Agric. Alex. Univ. Alexandria, Egypt.
Ahmed, M. Abd EL-Sattar. 2000. Comparison of single trait with multiple trait selection in barseem clover (Trifolium alexandrinum, L) J. Agric. Sci. Mansoura Univ., 25(8): 4601 - 4613. Mansoura Univ; Egypt.

Ahmed, M. Abd EL-Sattar. 2006. Variability, correlations and path-coefficient analysis in two populatios of multi-cut berseem clover.Alex.J.Agric.res. 51(2): 63-72.

Akintunde, A. 2012. Path analysis step by step using Excel. Journal of Technical science and Technologies 1(1): 9-11.

Annicchiarico, P. 1993. Variation for dry matter yield, seed yield and other agronomic traits in ladino white clover land races and natural populations. Euphytica 71(1-2):131-141.

Bakheit, B.R. and E.E. Mahdy, 1988. Improving barseem clover(Trifolium alexandrinum, L.) through pedigree selection among and within farmer's seed lots. Assuit J. Agric. Sci., 19(3): $267-278$.

Bakheit, B.R., 1986. Genetic variability, genotypic and phenotypic correlations and path coefficient analysis in Egyptian clover (Trifolium alexandrinum, L.). Journal of Agronomy and Crop Science 157, 58 - 66.

Crusius, A.F.,1997. Evaluation of the variability of agronomic traits of a population of Trifolium pretense,L.MSc. Federal university of Rio Grande do sul, Brazile.

Dewey, D.R., and K.H. Lu, 1959. A correlation and path coefficients analysis of components of crested wheatgrass seed production. Agron. J. 51, 511-518.

Iannucci, A and P. Martiniello. 1998. Analysis of seed yield component in four mediterranian annual clovers. Field crop Research. 55(3): 235-243.

Jahufer, M.Z.Z. and F.I. Gawler, 2000. Genotypic variation for seed yield components in white clover (Trifolium repens, L). Australian Journal of Agricultural Research 51(6): 657-663.

Lord.J.M. and D.Kelly.1999. Seed production in Festuca novae-zolandial: the effect of altitude and pre-dispersal predation. New Zealand Journal of Botany, 37(3): 503-509.

Radwan, M.S., R. Shabana, A.M. Rammah, and M.A. EL-Nehrawi, 1983. Variability and combining ability estimates in farmers seeds lots of Egyptian clover (Trifolium alexandrinum, L). $1^{\text {st }}$ Hon. Con. Agric. Bot Sci. 27-28April, 1983, $86-105$.

Vencovsky, R. and P.Belly. 1992. Genetic Biometrics In Plant Breeding. Ribeirao Preto: The Brazilian Society of Genetics.486p. 


\section{التلازمات القياسية وتحليل معامل المرور لمحصول البذرة في اربعة عثائر من}

\section{"Trifolium alexandrinum, L." البرسيم المصري متعدد الحثّات}

$$
\begin{aligned}
& \text { أسماء محمد سمير راضي } \\
& \text { قسم علوم المحاصيل- كلية الزر اعة (الثاطبي) - جامعة الاسكندرية. } \\
& \text { الملخص العربي }
\end{aligned}
$$

الهدف من الدراسة الحالية هو تقدير الدور الفعال لمكونات محصول البذرة لتحديد محصول البذرة في البرسيم

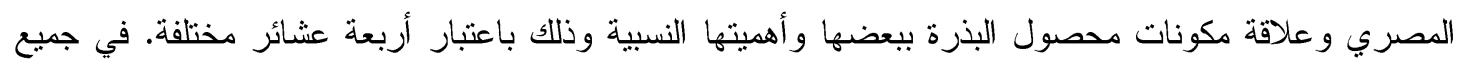
العشائر الدروسة اتضح ان صفة عدد النورات/نبات كانت أقوي الصفات ارتباطا موجبا مع محصول البذرة الكلي. بينما كانت صفة وزن البذور/ النورة لها درجة ارتباط متوسطة مع محصول البذرة الكلي في ثلاث من الاربعة

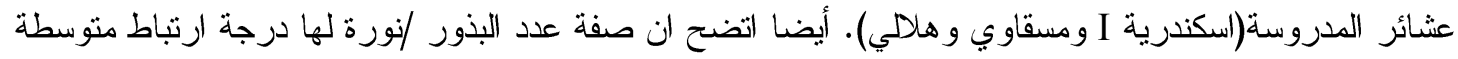
مع محصول البذرة الاجمالي في عشيرتان فقط(مسقاوي وهلالي). وقد سجلت أقوي علاقة تلازم موجبة بين عدد الندان

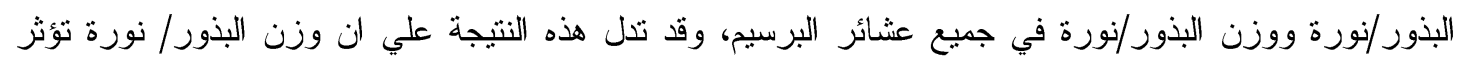

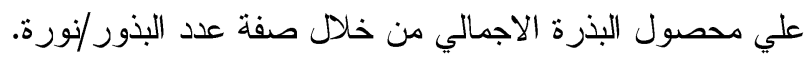

